\title{
Role of Micro Enterprises in Women Empowerment: Evidence from a Field Study of 'Kudumbashree' Units in Ernakulam District in Kerala
}

\author{
Shihabudheen N \\ Ph.D Research Scholar, Dept. of Applied Economics Cochin University of Science and Technology (CUSAT),
}

\begin{abstract}
The role of micro enterprises in rural development and women empowerment is widely recognized the world over, particularly in developing nations like India. Micro enterprises play a vital role in poverty alleviation and socio-economic development of the poor, and help to bring about equitable and balanced economic development with relatively low amount of capital investment. This paper looks into the role of micro enterprises in women empowerment by taking the specific case of micro enterprises functioning under 'Kudumbashree' - the flagship poverty alleviation project sponsored by Government of Kerala.
\end{abstract}

\section{Introduction}

It is well recognized in the literature that small scale enterprises (SSEs), particularly micro enterprises the lowest strata among the SSEs, play a vital role in the economic development of all nations, both developed and developing. Further, these enterprises ensure that the development is equitable, balanced, and devoid of gender disparities. Moreover, the capital investment involved is relatively very low. Accordingly, the significance of micro enterprises is high in respect of developing nations like India. In spite of the many favourable features of micro enterprises (or, SSEs in general), governments of developing countries showed lesser concern for SSEs until at least the 1970s (Little et. Al., 1987) It is a well established fact that these enterprises survive in large numbers and employ many people in the industrial countries. This fact is often quoted as a major reason for SSE development in the developing counties, including India. In respect of India, the peculiar capability of small enterprises in bringing about faster economic development was acknowledged even during the early years of the Plan era, despite the fact that The Industrial Policy Resolution 1956 favoured priority to heavy industry. For instance, the Karve Committee Report (1956) has stated that under-development by its very nature implies the existence of a large volume of unemployment and this problem can be addresses through promotion of small enterprises. The small enterprises used to play a cardinal role in the rural development of the adjoining regions, because of their employment generation capacity, local sourcing of inputs etc.

SSEs are often referred to within the broader framework of Small- and Medium-scale Enterprises (or, SMEs in short). SMEs play a vital and strategic role in socio-economic growth of any nation, as well as balanced and equitable distribution of the national resources. It is estimated that SMEs 'constitute as high as 90 percent of enterprises in most countries worldwide and are the driving force behind a large number of innovations and contribute to the growth of the national economy through employment creation, investments and exports' (Government of India Report, 2007) The contribution of SMEs toward poverty reduction and wider distribution of wealth in the developing economies need not be over-emphasized.

The term, 'empowerment' particularly when it refers to that of women, involves undoing negative social constructions, so that people affected can perceive themselves as having the capacity and right to act and have influence (Rowlands, 1995). According to Rao and Keller (1995), women empowerment is defined as "the capacity of women to be economically self-sufficient and self-reliant with control over decisions affecting their life options and freedom from violence". The definition of empowerment as per the United Nations (UNDP 2001) is the process by which women take control and ownership of their lives through expansion of their choices. Accordingly, empowerment refers to acquiring the ability to make strategic life choices in an environment where such an ability has previously been denied or not available. Two vital processes are observed to be vital for empowerment of women. The first one is social mobilization and collective agency, because poor women often lack the basic capabilities and self confidence that equip them to counter and challenge the disparities and barriers against them. The second process is economic security, because as long as economic deprivation and livelihood insecurity prevail women would not be able to mobilize. 


\section{Objectives of the Study}

In the above backdrop, the objectives of this paper are set as follows:

(i) To make an overall study of 'Kudumbashree' - the poverty alleviation programme of Government of Kerala, and the micro enterprises under it run by rural women;

(ii) To assess the role of micro enterprises under 'Kudumbashree' in bringing about empowerment of rural women entrepreneurs that they represent;

(iii) To make meaningful suggestions for more effective functioning of micro enterprises for enabling enhanced empowerment of rural women based on the findings of the study.

\section{Methodology of the Study}

The study is descriptive-analytical in nature, and uses both primary and secondary data. Primary data is collected from a sample of 10 micro enterprises representing 50 rural women members of "Kudumbashree'; five members each in each of the micro enterprises from Kottappady Panchayat in Ernakulam District. From the 50 women members as above, the relevant information is collected using a carefully designed Questionnaire. Popular statistical tools are used for data analysis.

\section{Kudumbashree" in Kerala and its Role in Women Empowerment: An Overview}

Kerala has got an appreciable track record of women empowerment in the whole of India. Apart from improving the socio-economic status of women, there is significant political empowerment also as they become participants in the decision-making process as members of various committees. Likewise, ownership of land, house or other assets in due course, also makes them empowered. A recent study done by Bina Agarwal in Kerala has found that women's risk of physical violence from husbands is dramatically less if they own hand or a house. The incidence of violence is 49 per cent among women without property, but 18 per cent among land owning women and 7 per cent of they own both land and house.

It was as part the decentralization measures initiated by the Government of Kerala in October 2005 and August 2006, that the idea to universalize the Anti-Poverty Programme of the State under the name of "Kudumbashree" took shape. Accordingly, Kudumbashree, the State Poverty Eradication Mission (SPEM), was launched by Government of Kerala in 1998 with the active support of Government of India and NABARD for wiping out absolute poverty within a period of 10 years. The project is implemented through Local Self Governments empowered by the 73rd and 74th Constitutional amendments. The slogan of the Mission is "Reaching out to families through Women and reaching out to community through Families". Kudumbashree is a holistic, participatory, women oriented innovative overarching poverty reduction approach. 'Kudumbashree' envisages prosperity of the economically backward families in the state with multiple programmes that will provide them information, create awareness, build up their capability and capacity, enhance their confidence and show them opportunity for better social security and empower them physically, socially, economically and politically. As of 2009, over 3.6 million women participate in the Kudumbashree movement in the state cutting across political ideologies and religious faiths. Within a short span of 12 years, Kudumbashree could bring about considerable change in the lives of women of Kerala by converging resources, ideas and programmes of various departments through the Community Development Society (CDS) system. Recent study by Manoj P K (2010)[4] has highlighted the women empowerment potential of 'Kudumbashree'. Another study by Manoj P K (2010)[5] has looked into a specialized housing microfinance scheme 'Bhavanashree' of Kudumbashree' and its potential in empowering the poor. Yet another study by the same author Manoj P K (2012)[6] has studied in detail the role of technology in women empowerment in Kerala.

\section{1. "Kudumbashree" Programme in Kerala: The Startegy}

(i) Identification of poor families using a non-monitory poverty index

(ii) Organizing the poor to a 3-tier Community Based Organization (CBO)

(iii) Empowerment of women through Community Based Organizations.

(iv) Formation of Informal Bank of Poor women operating round the clock throughout the year, starting from thrift \& credit operations

(v) Formation of micro-enterprises.

(vi) Convergent Community Action.

(vii) Strong liaison with LSGs

(viii) Intervention in Anti Poverty Sub Plan, Women Component Plan, Local Economic Development of local self governments

(ix) Community monitoring mechanism for local development 


\section{2. "Kudumbashree" Programme in Kerala: The Structure}

Kudumbashree has developed an innovative methodology to identify the poor using non-economic parameters and organized the poor under a well networked Community Based Organization (CBO). The noneconomic parameters are transparent and simple that can be used by the community.

\section{- Neighbourhood Group (NHG)}

"Kudumbashree" has got a three-tier Community Based Organisation (CBO) is in action. The lowest tier constitutes the NHG, consisting of 20-40 women members selected from economically backward families. Meetings are convened on a weekly basis in the houses of NHG members. In the weekly meeting all members bring their thrift, which will be collected and recycled, to the system by way of sanctioning loans. Micro plans for addressing poverty issues are also prepared after taking stock of the situation (Figure I). In each NHG from among the poor women, five volunteers are selected for undertaking various functional activities viz. (i) Community Health Volunteer, (ii) Income generation activities volunteer (IGA), (iii) Infrastructure Volunteer, (iv) Secretary, and (v) President

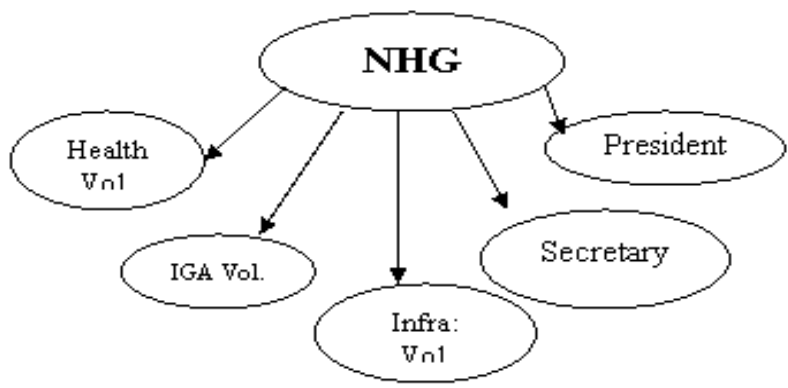

Figure I: Structure of NHG- the lowest Tier in the 3-Tier "Kudumbashree" Set up.

\section{- Area Development Society (ADS)}

The second tier is the Area Development Society, which is formed at ward level by federating all the NHGs in the ward. The activities and the decision in the ADS are decided by the representatives of the women elected from various NHGs. The Area Development Society function through the following bodies viz. (1) General Body - consisting of all President/Chairpersons, Secretaries, and 3 sectoral volunteers such as Health, Income Generation and Infrastructure volunteers of federated NHGs; (2) Governing Body - constituted by electing a President, Secretary and five member Committee from among the General Body. (Figure II)

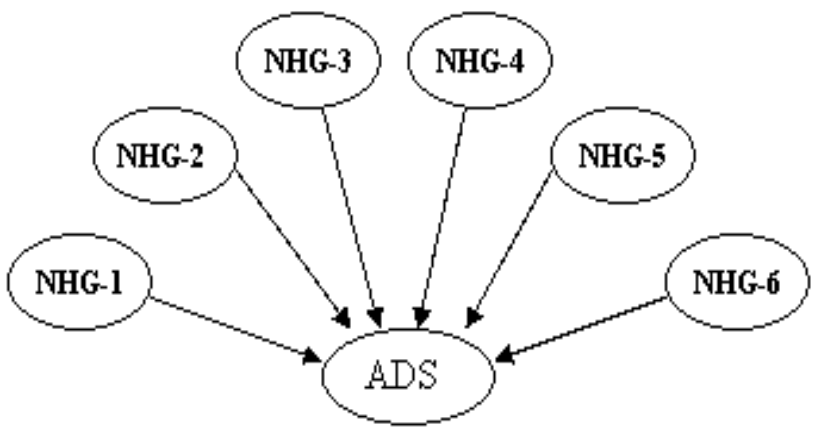

Figure (II): Structure of ADS- the Second Tier in the 3-Tier "Kudumbashree" Setup

\section{- Community Development Society (CDS)}

CDS is the top tier in the 3-Tier structure. At the Panchayat/Municipal level a Community Development Society (CDS), a registered body under the Charitable Societies Act is formed by federating various ADSs. The CDS functions through the following bodies viz. (1) General Body - It consists of all ADS Chairpersons and ADS Governing Body members along with representatives of Resource Persons, Officers of the Local Body who are involved in implementing various Poverty Alleviation and Women Empowerment Programmes; (2) Governing Body - The Governing Body consists of President,Vice President, Member Secretary and selected Committee Members. The President will be elected whereas the Member Secretary is the Project Officer of UPA in urban CDS or a charge officer appointed by the Grama panchayat in rural CDS. Other Government Officials of the LSG with stake in poverty reduction are ex-officio members of the CDS. 


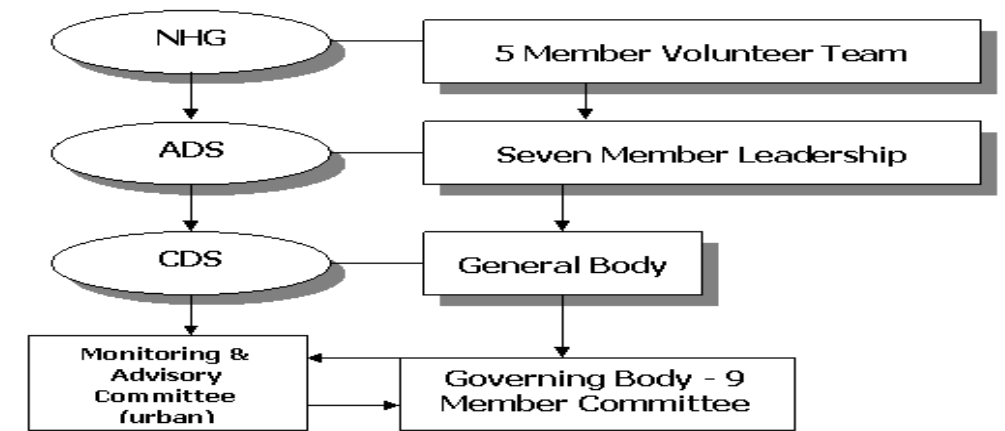

Figure III: The Three-Tier Structure of "Kudumbashree" in Kerala.

\subsection{Economic Development Activities of "Kudumbashree": An Overview}

Thrift \& Credit: Kudumbashree promotes Thrift mobilization by setting up Thrift \& Credit Societies at NHG level to encourage the poor to save and to provide them cost effective and easy credit. Thrift and credit Societies facilitate easy and timely credit to the un-reached. The amount of loan and the priority of disbursement are decided by the NHG. The repayment is collected weekly during the routine NHG meetings. The total thrift collected by NHGs in the state comes to Rs 844.95 crore and the internal loans generated are to the tune of Rs.2255.59 crore.

\section{Linkage Banking:}

The Bank Linkage programme has helped the NHGs to augment their existing resources collected through thrift. The efficiency and effectiveness of the NHGs are verified on the basis of some objectively verifiable and easily identifiable parameters. NABARD has developed a 15-point index for rating NHGs on the basis of which they will be allowed to link with various banks under the Linkage Banking Scheme. The total amount which has been mobilized under linkage banking is Rs 461.81 and 87715 NHGs have availed of the loans.

\section{Micro Enterprise:}

Kudumbashree views Micro Enterprise Development as an opportunity for providing gainful employment to the people below poverty line and thereby improving their income and living standard. Kudumbashree considers micro enterprise development as an emerging process which will start with low capital low risk and low profit at the initial stage which will gain momentum and later switch to low to medium capital and then to low to medium risk. Micro enterprises facilitated by Kudumbashree fall under the banner of Rural Micro Enterprise (which takes after the SGSY pattern), Yuvasree (which caters to educated youth), and the SJSRY programme (which is implemented through the agency of Kudumbashree).

\section{Role of Micro Enterprises under "Kudumbashree" in Women Empowerment}

As already noted there are 50 rural women entrepreneurs in the sample of 10 micro enterprises selected for the study, cutting across different religions and castes. A brief discussion on the socio-economic and demographic profile of these women entrepreneurs is given below. (Tables I to III).

Table I: Age Profile of the Sample of Women Micro Entrepreneurs under Study

\begin{tabular}{|l|c|c|c|c|}
\hline \multirow{2}{*}{ Particulars } & \multicolumn{4}{|c|}{ Profile of the rural women micro entrepreneurs } \\
\cline { 2 - 5 } & Below 35 & 35 to50 & Above 50 & Total \\
\hline No. of workers in each group & 09 & 34 & 07 & 50 \\
\hline Percentage Share & 18 & 68 & 14 & 100 \\
\hline
\end{tabular}

(Source: Field Survey)

It is noted that 18 percent of the workers are below 35 years, 68 percent within $35-50$ years and the rest 14 percent above 50 years. Thus, middle-aged (35-50 years) people account for relatively larger share in the sample workers under study as it is as high as 68 percent (Table I).

Table II: Marital Status of the Sample of Women Micro Entrepreneurs under Study

\begin{tabular}{|l|c|c|c|c|c|}
\hline \multirow{2}{*}{ Type of Micro Enterprises } & \multicolumn{2}{|c|}{ Married } & \multicolumn{2}{|c|}{ Unmarried } & \multirow{2}{*}{ Total } \\
\cline { 2 - 6 } & No & Percent & No & Percent & \\
\hline No. of workers in each group and Percentage & 46 & 92 & 04 & 08 & 50 \\
\hline
\end{tabular}

(Source: Field Survey) 
It is observed that as high as 92 percent of the sample micro entrepreneurs are married people and the balance 08 percent alone are unmarried micro entrepreneurs (Table II).

Table III: Religion of the Sample of Women Micro Entrepreneurs under Study

\begin{tabular}{|l|c|c|c|c|}
\hline \multirow{2}{*}{ Particulars } & \multicolumn{3}{|c|}{ Religion } & \multirow{2}{*}{ Total } \\
\cline { 2 - 4 } & Hindu & Muslim & Christian & \\
\hline No. of workers in each group & 27 & 10 & 13 & 50 \\
\hline Percentage Share & 54 & 20 & 26 & 100 \\
\hline
\end{tabular}

(Source: Field Survey)

From Table III it is noted that majority of the women entrepreneurs are from the Hindu religion and they account for 54 percent of the total. Secondly comes Christian women entrepreneurs who account 26 percent, and the rest 20 percent goes to Muslim entrepreneurs.

\section{VI. "Kudumbashree" Micro Enterprises and Women Empowerment - Study Findings}

For assessing the women empowerment resulting from micro entrepreneurial initiatives of such "Kudumbashree" women the totally 10 factors as shown in Table IV are considered:

Table IV "Kudumbashree" Micro Entrepreneurs- Level of Empowerment

\begin{tabular}{|c|c|c|c|c|}
\hline \multirow{2}{*}{$\begin{array}{l}\text { Factors related to Socio-Economic and Political } \\
\text { Empowerment of Women Micro Entrepreneurs } \\
\text { under "Kudumbashree" }\end{array}$} & \multicolumn{3}{|c|}{ Level of Empowerment } & \multirow{2}{*}{$\begin{array}{l}\text { Average } \\
\text { Weighted } \\
\text { Score }\end{array}$} \\
\hline & 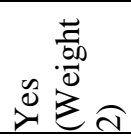 & 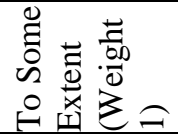 & 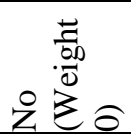 & \\
\hline Confidence to promote own micro enterprise & 27 & 17 & 6 & 1.42 \\
\hline Managerial/administrative capability & 19 & 23 & 8 & 1.22 \\
\hline Inspiration to undertake risk & 25 & 19 & 6 & 1.38 \\
\hline Generation new business ideas & 18 & 29 & 3 & 1.3 \\
\hline Freedom to spend and save the earnings & 31 & 16 & 3 & 1.56 \\
\hline Freedom to decide on children's education & 19 & 25 & 6 & 1.26 \\
\hline Deciding on purchase of household assets & 18 & 24 & 8 & 1.2 \\
\hline Public speaking ability & 18 & 25 & 7 & 1.22 \\
\hline Expressing opinion in a meeting/discussion & 29 & 15 & 6 & 1.46 \\
\hline To raise voice against injustice & 23 & 15 & 12 & 1.22 \\
\hline
\end{tabular}

(Source: Field Survey)

From Table IV and Figure I, it is noted that women micro enterprises under "Kudumbashree" offer reasonably high level of empowerment to its members. It may be noted that the high levels of empowerment is there for factors like freedom to spend and save earnings (score 1.56), expressing opinion in a meeting/discussion (score 1.46), confidence to promote own micro enterprise (1.42) and inspiration to undertake risk (1.38). In respect of other factors also, there is moderate level of empowerment as evidenced by scores ranging from 1.3 to 1.2 .

In short, there is high empowerment potential for micro enterprises under "Kudumbashree". Besides, from the high scores of the four factors as noted above it may be concluded that there is high scope for socioeconomic as well as political empowerment of rural women because of their participation in the micro enterprises under "Kudumbashree". 
Figure I:“Kudumbashree” Micro Entrepreneurs- Level of Empowerment (Descending Order)

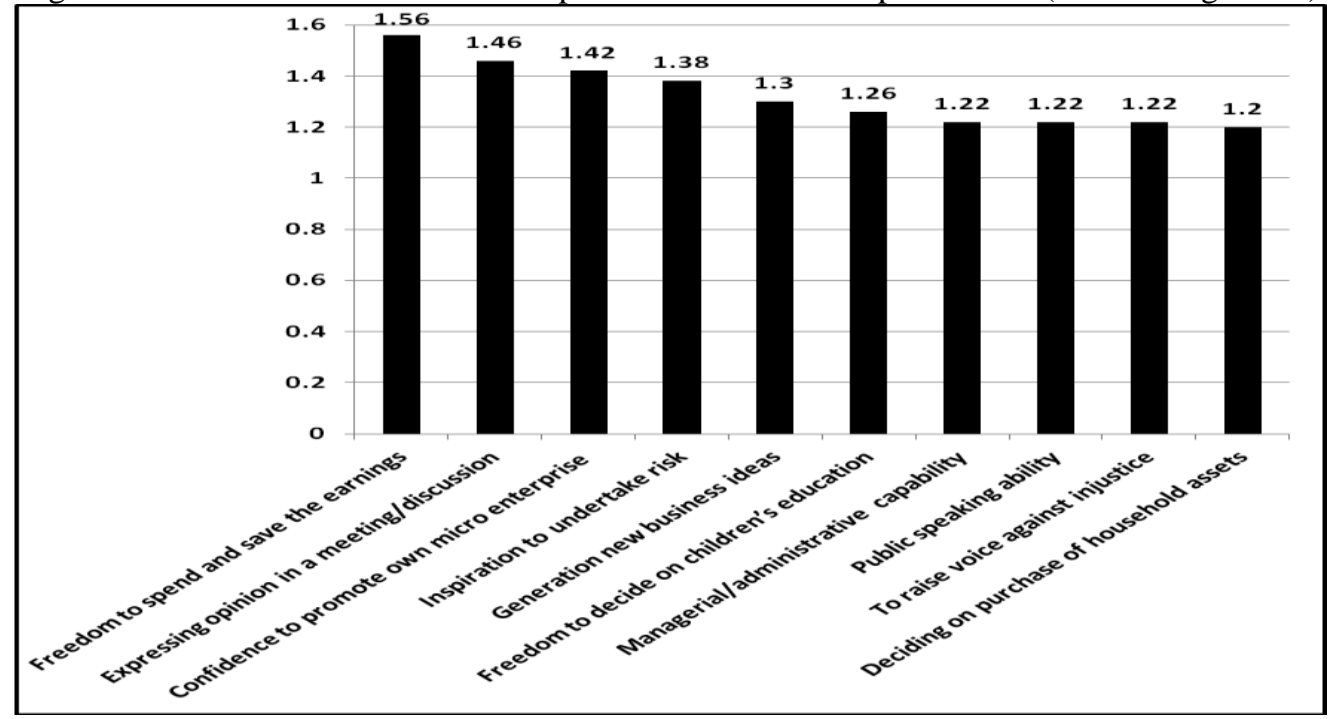

(Source: Computed from the Field Survey findings given in Table IV)

VII. Interpretation of Findings and Suggestions

(i) From the findings of the study it is noted that micro enterprises significantly enhances the individual and family empowerment of rural women by ensuring freedom to spend and save earnings. Simultaneously, it improves the confidence to promote own micro enterprises and also inspiration to undertake risk. These facts, when considered together points to the logical conclusion that suitable credit facilities if extended to interested "Kudumbashree" micro entrepreneurs, they can come up with their own individually managed micro enterprises meaningfully (as against collective endeavors comprising of 5 members each under "Kudumbashree" micro enterprises). Commercial banks can extend suitable credit under their MSME/SSI financing schemes meaningfully to interested "Kudumbashree" micro entrepreneurs individually too based on their performance track record under "Kudumbashree" micro enterprises.

(ii) The enhanced ability to express their opinions in meetings or discussions make "Kudumbashree" micro entrepreneurs empowered politically too, and they become better equipped to occupy responsible positions under Local Self Government (LSG)/ Punchayati Raj Institutions (PRIs) /similar institutions. While nominating or selecting people to different local bodies as above due preference be given to those having experience of working under "Kudumbashree" micro enterprises, so that their skills and experience could be meaningfully utilized. The relatively high or moderate score of 1.22 for the factor 'To raise voice against injustice' further reinforces the above viewpoint.

(iii) The high moderate score for generation of business ideas (score 1.3) as well as factors like managerial /administrative capability, and public speaking ability (score 1.22 each) further point to the need for encouraging additional investment in business by "Kudumbashree" micro entrepreneurs either collectively or individually.

\section{Concluding Remarks}

In view of the foregoing, it may be opined that micro enterprises under "Kudumbashree" have got very high potential for women empowerment. In fact, "Kudumbashree" model has already become a role model for the entire nation for its systematic functioning and also corruption-free implementation various Central Government schemes like MGNREGA. In the above backdrop, it may be pointed out that given the women empowerment potential of "Kudumbashree", these enterprises should be promoted more aggressively by the authorities, and additional credit exposures be extended to promising micro enterprises as well as members (entrepreneurs) of such enterprises.

\section{Acknowledgement}

The author acknowledges his heart-felt thanks and gratitude to his Ph.D research supervisor Dr. Manoj P K, Assistant Professor, Department of Applied Economics, CUSAT for giving the necessary guidance for data collection and analysis for this paper, including provision of some secondary data and preliminary information relevant to this study. 


\section{References}

[1] Kabeer, N., 2001., "Resources, agency, achievements: reflections on the measurement of women empowerment", in Discussing Women's Empowerment - Theory and Practice, SIDA Studies No. 3.

[2] Llanto, G. M., 2004, "Microfinance in Philippines", in Ghosh, R (Ed.), Microcredit in Asia,Concepts and Cases, ICFAI University Press, Hyderabad, 2005.

[3] Mayoux, L. (1997)., The Magic Ingredient? Microfinance and Women Empowerment, a Briefing, Paper contributed to the Microcredit Summit, Washigton, USA.

[4] Manoj P K, ""Microfinance for Economic and Political Empowerment of Women in India: a Study with Focus on "Kudumbashree" Experience in Kerala", In Arunachalam (Ed.), Economic Impact of Political Empowerment of Women in India, Global Research Publications, 4830/24, I Floor, Ansari Road, Darya Ganj, New Delhi, First Ed., 2010.

[5] Manoj P K, "Housing Microfinance for Solving the Housing Problem of the Poor in India: Lessons from 'Bhavanashree' Experience in Kerala" ", In Arunachalam (Ed.), Micro Credit and Rural Poor Empowerment, Vol II, Global Research Publications, 4830/24, I Floor, Ansari Road, Darya Ganj, New Delhi, First Ed., 2010.

[6] Manoj P K, “Technology for Women Empowerment: A study with a Focus on 'Kudumbashree' Programme in Kerala State” In Meera Bai (Ed.), Technology for Women Empowerment Issues and Challenges, Serials Publications, 4830/24, Ansari Road, New Delhi-110002, First Ed., 2012.

[7] Rajagopalan, S., 2006, "DHAN Foundation: Microfinance through Community Banking”, in Bhargava, H., and Sharma, R. (Eds), Managing Microfinance, A Corporate Approach, ICFAI University Press, Hyderabad, 2006, pp. 233-245.

[8] Reddy, C. S., Livingstone, J., and Manak, S. , 2006, "Institutionalizing Support to SHGs: The APMAS Experience", in Bhargava, H., and Sharma, R. (Eds), Managing Microfinance, A Corporate Approach, ICFAI University Press, Hyderabad.

[9] Ruomei, S., 2003, "The Development of Micrifinance in China", in Ghosh, R (Ed.), Microcredit in Asia,Concepts and Cases, ICFAI University Press, Hyderabad, 2005.

[10] Swain, R. Bali, and Wallentin, F. Yang, 2007, "Empowering Women through Microfinance", Poverty in Focus, UNDP, Dec. 2007.

[11] United Nations Development Programme, 1997., "Sustaining Livelihoods: Promoting Informal Sector Growth in Pacific Island Countries".

[12] United Nations Development Programme, 2001., "Participatory Governance, People's Empowerment and Poverty Reduction", UNDP Conf. Paper Series.

[13] World Bank, 1998, PREMnotes, No. 8, Washington, World Bank, USA.

[14] Yunus, Muhammed., \& Alan, Jolis, 1998., Banker to the Poor: The Autobiography of Muhammed Yunus, London, Aurum Press.

[15] Zaman, H. (2001), "Assessing the Poverty and Vulnerability Impact of Microcredit in Bangladesh: A Case Study of BRAC", background paper for World Bank, World Development Report 2000/2001, Washington, World Bank. 